\title{
ASSESSMENT OF GENETIC DIVERSITY IN CULTIVATED TOMATO (SOLANUM LYCOPERSICUM L.) GENOTYPES USING RAPD PRIMERS
}

\author{
Saida SHARIFOVA ${ }^{1,3^{*}}$, Sabina MEHDIYEVA ${ }^{2,3}$, Konstantinos THEODORIKAS $^{3}$, \\ Konstantinos ROUBOS ${ }^{3}$ \\ ${ }^{1}$ Department of Vegetable and Melon Plants \\ ${ }^{2}$ Department of Cytogenetics, Genetic Resources \\ Institute of Azerbaijan National Academy of Sciences, Baku, Azerbaijan \\ ${ }^{3}$ Laboratory of Plant Molecular Biology and Plant Propagation, \\ Alexander Technological Educational Institute of Thessaloniki, Thessaloniki, Greece
}

Received: April 24, 2013; Accepted: June 17, 2013

\begin{abstract}
Random Amplified Polymorphic DNA (RAPD) analysis was carried out on 19 Azerbaijan tomato genotypes, both cultivars and local populations. A total of 26 amplified products were revealed by 6 primers. The genetic similarity among evaluated genotypes ranged from 0.188 to 1.000 . The lowest similarity was observed between cultivars 'Azerbaijan' and 'Shakar' $(0.188)$, while the highest between 'Elnur' and 'Garatag' (1.000). The Unweighted Pair Group Method with Arithmetic Mean (UPGMA) cluster analysis based on Jaccard's similarity coefficient divided genotypes into four main groups. The first group was the largest and consisted of 12 genotypes, while the fourth group was the smallest consisted of 1 genotype only. The most polymorphic primer was OPB-18 that presented a genetic diversity index of 0.823 , while the least informative was primer OPG-17 with an index of 0.349 . The average genetic diversity calculated from RAPD data was 0.665 .
\end{abstract}

Key words: Azerbaijan; breeding; polymorphism; RAPD; similarity; tomato

\section{INTRODUCTION}

The cultivated tomato (Solanum lycopersicum L.) is economically one of the most important and widely grown plants of the Solanaceae family. It is estimated that over 62800 accessions of the cultivated and wild species of tomato are maintained in gene banks around the world, including those at the Asian Vegetable Research and Development Center (AVRDC) in Tainan, Taiwan (http://www.avrdc.org), the Plant Genetic Resources Unit (PGRU) in New York, USA (http://www.usda.gov), and at the CM Rick Tomato Genetics Resource Center (TGRC), University of California in Davis, USA (http://tgrc.ucdavis.edu). The European Cooperative' Programme for Plant Genetic Resources (ECPGR) tomato database contains passport information of more than 20000 accessions of several tomato species (http://documents.plant.wur.nl/cgn/pgr/tomato).

The tomato core collection of European Solanaceae database is composed of about 7000 domesticated (S. lycopersicum L.) lines, along with representatives of wild species (www.eusol.wur.nl). The cultivated tomato is a well-studied species in terms of genetics, genomics, and breeding (Foolad 2007). It has been one of the first crop plants for which a genetic linkage map was constructed (Rick 1975; Tanksley and Rick 1980; Bernatzky and Tanksley 1986; Tanksley et al. 1992). Currently, there are several molecular maps based on crosses between the cultivated and wild species of tomato (Grandillo and Tanksley 1996; Bernacchi and Tanksley 1997; Chen and Foolad 1999; Frary et al. 2004).

DNA fingerprinting is a convenient tool for assessing genetic diversity (Park et al. 2004; Semagn et al. 2006; Mondini et al. 2009). The characterization of various plant genetic resources with molecular markers offers a unique opportunity to define significant marker-trait associations of biological and agronomic interest (Parmar 2010).

Cultivated tomato (Solanum lycopersicum L.) is a species in which biochemical and molecular markers such as isozymes and RFLPs yielded limited amount of information due to the lack of vari- 
ability, as a consequence of self-pollination in combination with the narrow genetic base of the modern cultivars (Miller and Tanksley 1990; Breto et al. 1993; Alvarez et al. 2001). Nevertheless, different types of molecular markers such as RFLPs, AFLPs, SSRs, CAPS, and ESTs have been developed and mapped onto the 12 tomato chromosomes (Broun and Tanksley 1996; SalibaColombani et al. 2000; Suliman-Pollatschek et al. 2002; Frary et al. 2005). Since the successful construction of RAPD markers gene mapping in tomato by Klein-Lankhorst et al. (1991), the application of the RAPD technique in varietal identification of tomato has been well explored (Noli et al. 1999; Rajput et al. 2006; Singh et al. 2007).

The main collections of vegetable plants in Azerbaijan are conserved in the National Gene Bank in Genetic Resources Institute (GRI), in the Scientific Research Institute of Vegetable Growing, and in the Azerbaijan State Agricultural Academy (Sharifova 2012). The study of genetic diversity is necessary for efficient utilization, conservation and management of genetic resources deposited in gene banks. Since the morphological characterization does not provide accurate information necessary to distinguish different genotypes, further assessment of collected germplasms at the molecular level is required (Carmen de Vicente et al. 2006; Ferreira 2006). The present study was conducted in order to examine the genetic diversity of the local tomato genotypes collected at GRI using RAPD markers.

\section{MATERIALS AND METHODS}

Plant material consisted of 19 different genotypes (cvs 'Garatag', 'Elnur', 'Shakar', 'Nuru', 'Gurman', 'Ilkin', 'Zafar', 'Azerbaijan', 'Leyla', 'Zarrabi' and local populations 'Sabirabad', 'Saatly', 'Nakhchivan', Absheron-1, Absheron-2, Absheron-3, AG-1222, AG-1223, and AG-1224) of cultivated tomato (S. lycopersicum L.). All samples were obtained from the Gene Bank of the GRI of the Azerbaijan National Academy of Sciences (ANAS) (http://www.genres.az).

DNA was extracted from fresh leaves of seedlings according to Roubos et al. (2010). The quality and quantity of nucleic acids was determined on the basis of UV spectrum using Nanodrop ND1000 spectrophotometer. Ten RAPD primers: OPA-14, OPA-15, OPB-17, OPB-18, OPC-08, OPC-09, OPG-17, OPU-03, OPU-14, and OPV-19 (Operon Technologies Inc., USA) were used for amplification. Polymerase chain reactions (PCRs) were performed in $25 \mathrm{~mm}^{3}$ of reaction mixture containing $1 \times$ PCR buffer (Invitrogen), $0.2 \mathrm{mM}$ of each dNTP (Invitrogen), $1.5 \mathrm{mM} \mathrm{MgCl}_{2}, 0.4 \mathrm{mM}$ of a primer (Invitrogen), $50 \mathrm{ng}$ genomic DNA, and $1 \mathrm{U}$ Taq Polymerase (Invitrogen). Amplification

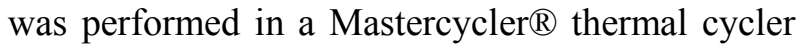
(Eppendorf). The cycling programs for DNA amplification consisted of denaturation for $2 \mathrm{~min}$ at $94{ }^{\circ} \mathrm{C}$ followed by 38 cycles of $60 \mathrm{~s}$ at $94{ }^{\circ} \mathrm{C}$ for denaturation, $60 \mathrm{~s}$ at $40^{\circ} \mathrm{C}$ for primer annealing and $60 \mathrm{~s}$ at $72{ }^{\circ} \mathrm{C}$ for extension. A final extension was at $72^{\circ} \mathrm{C}$ for $7 \mathrm{~min}$. PCR products were separated by electrophoresis in $1.5 \%$ agarose gel (Invitrogen) at $100 \mathrm{~V}$ for $1.5 \mathrm{~h}$. A 100-bp ladder (Invitrogen) was used as a size standard. Gels were visualized and photographed under UV light with the Molecular Imager ${ }^{\circledR}$ Gel Doc ${ }^{\mathrm{TM}}$ XR system (Bio-Rad) and then analysed with the Quantity 1.0 software (Bio-Rad).

Amplified fragments were scored for presence (1) or absence (0) of the respective bands in all the genotypes tested. After identification of the polymorphic bands, different patterns were identified among genotypes. The genetic diversity index was calculated for each primer and each pattern frequency using the formula:

$$
H=1-\Sigma P i^{2}
$$

where: $\mathrm{H}$ is genetic diversity index and $\mathrm{Pi}$ is pattern's frequency (Nei 1973).

Jaccard's similarity coefficients matrix and dendrogram were constructed using the unweighted pair group method with arithmetic mean (UPGMA) module of SPSS v.12.0 computer package (SPSS 2003).

\section{RESULTS AND DISCUSSION}

Four of the primers used (OPA-15, OPU-03, OPU-14 and OPA-14) did not provide any evaluable bands. The polymorphic bands obtained with the other primers: OPC-08, OPC-09, OPB-17, OPB-18, OPV-19 and OPG-17, were scored as 1 for presence or 0 for absence and imported into SPSS. A band was considered polymorphic if it was present or absent in at least 3 of the 19 accessions tested. A total of 26 scorable bands were obtained from 19 cultivated tomato accessions (Table 1).

A total of $65.3 \%$ of the produced bands showed polymorphism (Table 1). Primer OPV-19 and OPB-18 produced 4 polymorphic bands, while OPG-17 1 band only. Polymorphism percentage 
ranged from 50 to $100 \%$. Primer OPB-18 generated the greatest diversity index with a value of 0.823 , while primer OPG-17 showed the smallest diversity with an index of 0.349 . The average genetic diversity index was 0.665 (Table 1).

Table 1. List of primers, numbers of polymorphic and monomorphic bands, and genetic diversity index obtained with tomato genotypes

\begin{tabular}{lccccc}
\hline Primers & Sequences (5' - 3') & $\begin{array}{c}\text { Number } \\
\text { of bands }\end{array}$ & $\begin{array}{c}\text { Number of } \\
\text { polymorphic } \\
\text { bands }\end{array}$ & $\begin{array}{c}\text { Polymorphism } \\
\text { ratio, percentage } \\
(\%)\end{array}$ & $\begin{array}{c}\text { Genetic diver- } \\
\text { sity index }\end{array}$ \\
\hline OPC-08 & 5'-TGGACCGGTG-3' $^{\prime}$ '-CTCACCGTCC-3' & 4 & 2 & 50.0 & 0.681 \\
OPC-09 & 5'-CTCACGACGAG-3' $^{\prime}$ & 4 & 3 & 100.0 & 0.722 \\
OPB-17 & 5'-AGGGAACG & 3 & 75.0 & 0.662 \\
OPB-18 & 5'-CCACAGCAGT-3' & 5 & 4 & 80.0 & 0.823 \\
OPV-19 & 5'-GGGTGTGCAG-3' & 8 & 4 & 50.0 & 0.752 \\
OPG-17 & 5'-ACGACCGACA-3' & 2 & 1 & 50.0 & 0.349 \\
\hline Total & & 26 & 17 & 65.3 & 0.665 (aver.) \\
\hline
\end{tabular}

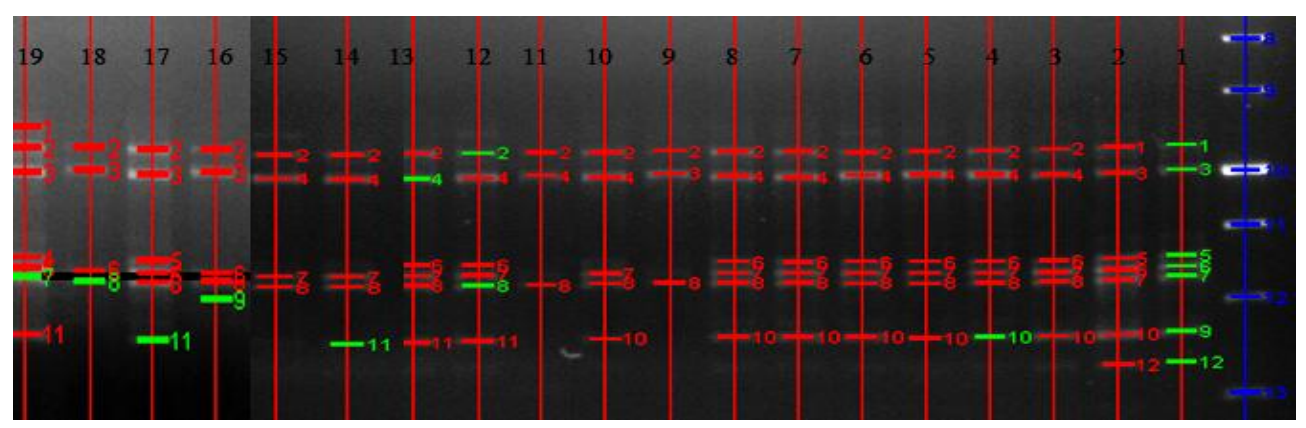

Figure 1. RAPD-PCR analysis with use of primer OPV-19 on 19 tomato genotypes. Shown is a gel picture after scoring with Quantity 1.0

The primers that were used in our study have been applied successfully for assessing different plant genotypes (Teixeira-Cabral et al. 2002; Tardin et al. 2003; Rana et al. 2005; Badjakov et al. 2006; Kawar et al. 2009; Butiuc-Keul et al. 2010). OPC-09 was used for coffee tree genotypes grouping analysis and amplified polymorphic markers (Teixeira-Cabral et al. 2002). Moreover, OPC-09 generated 17 bands, 13 of which were polymorphic in Indian cotton (Gossypium spp.) accessions (Rana et al. 2005). OPC-08 and OPG17 were used successfully for assessing genetic diversity in sugarcane cultivars (Kawar et al. 2009). OPB-17 was used by Butiuc-Keul et al. (2010) for analysing the genetic polymorphism in several cultivars of grapevine and 5 polymorphic fragments were obtained with Feteasca alba cultivars. OPB-19 and OPC-08 were used in assessing the genetic diversity of Bulgarian raspberry germplasms and generated high number of polymorphic bands in different lines (Badjakov et al. 2006). OPV-19 was used in research on twenty lettuce (Lactuca sativa L.) accessions and generated 2 polymorphic bands (Tardin et al. 2003). Ezekiel et al. (2011) have used 10 RAPD primers for characterization of Nigerian tomato cultivars and suggested that RAPD markers are efficient in characterization of tomato genotypes. In the above mentioned study, the primer OPB-18 recorded the highest percentage of polymorphism $(83.3 \%)$, as it revealed 5 polymorphic bands in 6 amplified fragments. Additionally, OPG-17 was one of the most effective fragment amplifiers (yielding up to 9 fragments), while the OPC-09 was the least effective with 2 fragments only. Four primers: OPA-15, OPU-03, OPU-14 and OPA-14, which did not generate any bands with our tomato accessions, amplified polymorphic products in Nigerian tomato cultivars, thus revealing the differences between Nigerian and Azerbaijan tomato genotypes.

According to Jaccard's similarity index, the lowest similarity of 0.188 and 0.2 was found between 'Azerbaijan' and 'Shakar' and between 'Shakar' and 'Saatly' cultivars, respectively. Similarity coefficient between 'Elnur' and 'Garatag' reached 1.000. The 'Leyla' and 'Zarrabi' genotypes 
gave the second highest ratio of 0.944 . High similarity index of 0.917 was also observed between AG1223 and 'Nuru' genotypes.

Ten genotypes in this study were known cultivars ('Garatag', 'Elnur', 'Shakar', 'Nuru', 'Gurman', 'Ilkin', 'Zafar', 'Azerbaijan', 'Leyla' and 'Zarrabi') while other 6 genotypes ('Sabirabad', 'Saatly', 'Nakhchivan', 'Absheron-1', 'Absheron2', 'Absheron-3') were collected from different regions of the country and included into the gene bank. Another three genotypes (AG-1222, AG-1223 and AG-1224) were registered as local genotypes in the gene bank, but there was no information about their origin(s). The last 9 accessions were registered as local population samples.

UPGMA average gene cluster analysis based on the Jaccard's similarity coefficient grouped the genotypes into four main clusters (Fig. 2). The first cluster represented 7 of 9 so-called local population samples. Three of these were collected from the Absheron region (Absheron-1, Absheron-2, and Absheron-3) and joined in the upper cluster, while another two ('Sabirabad' and 'Saatly') were local populations grown at the Aran region (Fig. 3 ). Yet another genotype represented in the first cluster ('Nakhchivan') was collected from the Nakhchivan Autonomous Republic of Azerbaijan. Moreover, the above cluster included five cultivars, of which 'Leyla' and 'Zarrabi' were mainly cultivated at the Lankaran region, 'Elnur' at the Lankaran and Guba-Khachmaz region, 'Azerbaijan' at the Ganja-Gazakh region, while 'Garatag' is an old cultivar that is not cultivated anymore and is threatened to extinct (Fig. 3). 'Nuru' cultivar that is located in the second cluster (Fig. 2), and is cultivated at the Lankaran and Guba-Khachmaz region, while the other cultivar of this cluster ('Gurman') can be found in different regions of the country (Absheron, Ganja-Gazakh). Cv. 'Gurman' is also threatened to extinct. Concerning the third cluster, 'Ilkin' cultivar can be found in all the vegetable producing regions shown in Fig. 3. 'Zafar' (third cluster) and 'Shakar' (fourth cluster) cultivars are also cultivated mainly at the Lankaran and GubaKhachmaz region. Concerning the genotypes with no specific information about their collecting sites, AG-1224 is located in the first cluster, AG-1223 in the second cluster and AG-1222 in the third cluster (Fig. 2).

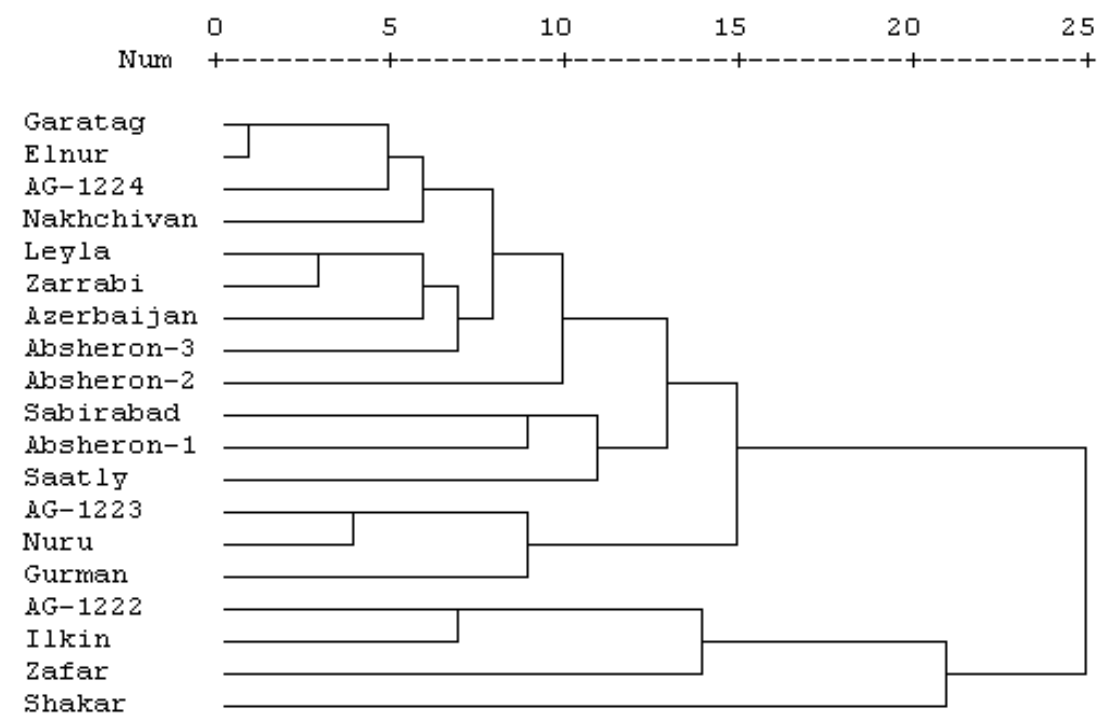

Figure 2. Dendrogram of 19 tomato genotypes revealed by UPGMA cluster analysis based on Jaccard`s similarity coefficients generated from RAPD markers 




Figure 3. Main vegetable producing economical regions of Azerbaijan

Although accessions with the same or adjacent geographic origin have the tendency to cluster together, accessions from different regions were also found to be closely related regardless of their geographic origin. This suggests that selection of parent genotypes for breeding should not be based on geographical origin only because this is not always an accurate indicator of genetic diversity (Keneni et al. 2005; Zvingila et al. 2005; Gashaw et al. 2007; Celka et al. 2010). The tendency of grouping genotypes with different geographical origins into the same cluster did not allow us also to make an assumption about the geographical origin of AG-1222, AG-1223, and AG-1224 genotypes.

In our experiment, two cultivars: 'Garatag' and 'Elnur' showed $100 \%$ similarity level based on 6 primers used (Fig. 2). This suggests that they belong to the same genotype. Nevertheless, 'Garatag' is the old cultivar whereas 'Elnur' is a breeding variety obtained by crossing 'Mayak $12 / 20$ ' and 'Azerbaijan' cultivars. Both of them are known genotypes and have been collected from the same city (Ganja). Therefore, we can suppose that a mistake occurred during either collecting or entering data into the database. Nevertheless, further studies with the use of morphological and molecular markers are required in order to come to more precise conclusions.

The results of the study allows to conclude that RAPD markers are effective in assessing and discriminating local tomato genotypes conserved at the gene banks in Azerbaijan. This is the first study on DNA fingerprinting of Azerbaijan tomato geno- types. Although the major cultivated local tomato genotypes in Azerbaijan have been described, further study is needed in order to elucidate the genetic structure of the local cultivars, populations, landraces, hybrids, introduced accessions, and all other tomato accessions deposited in the gene banks. Such studies should be useful both for identification of duplicate accessions and establishment of core collection in the gene banks, as well as for sustainable conservation of the genotypes collected. Precise molecular characterization of conserved collections will allow for more efficient management and utilization of genotypes in the breeding programs.

\section{Acknowledgements}

Research supported by the Erasmus Mundus Action 2 Program. We acknowledge the contributions of Professor Athanassios K. Roubos and Dr. Zeynal I. Akparov.

\section{REFERENCES}

Alvarez A.E., Van de Weil C.C.M., Smulders M.J.M., Vosman B. 2001. Use of microsatellites to evaluate genetic diversity and species relationships in the genus Lycopersicon. Theor. Appl. Genet. 103: 1283-1292. DOI: $10.1007 / \mathrm{s} 001220100662$

Badjakov I., Todorovska E., Condakova V., Boicheva R., Athnassov A. 2006. Assessment the genetic diversity of Bulgarian raspberry germplasm collection by microsatellite and RAPD markers. J. Fruit Ornam. Plant Res. 14: 61-76.

Bernacchi D., Tanksley S.D. 1997. An interspecific backcross of Lycopersicon esculentum $\times$ L. hirsutum: linkage analysis and a QTL study of sexual 
compatibility factors and floral traits. Genetics 147(2): 861-877. PMC1208205

Bernatzky R., Tanksley S.D. 1986. Toward a saturated linkage map in tomato based on isozymes and random cDNA sequences. Genetics 112(4): 887898. PMC1202783

Breto M.P., Asins M.J., Carbonell E.A. 1993. Genetic variability in Lycopersicon species and their genetic relationships. Theor. Appl. Genet. 86: 113 120. DOI: $10.1007 / \mathrm{BF} 00223815$

Broun P., Tanksley S.D. 1996. Characterization and genetic mapping of simple repeat sequences in the tomato genome. Mol. Gen. Genet. 250: 39-49. DOI: $10.1007 / \mathrm{BF} 02191823$

Butiuc-Keul A.L., Crăciunas C., Coste A., Fagaro M. 2010. Discrimination and genetic polymorphism in several cultivar of grapevine by RAPD markers. Rom. Biotechn. Lett. 15(1): 111.

Carmen de Vicente M., Felix Alberto G., Engels J., Ramanatha V.R. 2006. Genetic characterization and its use in decision-making for the conservation of crop germplasm. In: Ruane J., Sonnino A. (eds), The Role of Biotechnology in Exploring and Protecting Agricultural Genetic Resources. Food and Agriculture Organization of the United Nations, Rome, Italy, pp. 128-138.

Celka Z., Buczkowska K., Bączkiewicz A., Drapikowska M. 2010. Genetic differentiation among geographically close populations of Malva alcea. Acta. Biol. Cracov. Bot. 52(2): 32-41. DOI: 10.2478/v10182-010-0021-9

Chen F.Q., Foolad M.R. 1999. A molecular linkage map of tomato based on a cross between Lycopersicon esculentum and L. pimpinellifolium and its comparison with other molecular maps of tomato. Genome 42(1): 94-103. DOI: $10.1139 / \mathrm{g} 98-103$

Ezekiel C.N., Nwangburuka C.C., Ajibade O.A., Odebode A.C. 2011. Genetic diversity in 14 tomato (Lycopersicon esculentum Mill.) varieties in Nigerian markets by RAPD-PCR technique. Afr. J. Biotechnol. 10(25): 4961-4967. DOI: 10.5897/AJB11.144

Ferreira E.M. 2006. Molecular analysis of gene banks for sustainable conservation and increased use of crop genetic resources. In: Ruane J., Sonnino A. (eds), The role of biotechnology in exploring and protecting agricultural genetic resources. Food and Agriculture Organization of the United Nations, Rome, Italy, pp. 121-128.

Foolad R.M. 2007. Genome mapping and molecular breeding of tomato. Int. J. Plant Genomics. Volume 2007: Article ID 64358, p. 52. DOI: $10.1155 / 2007 / 64358$

Frary A., Fulton T.M., Zamir D., Tanksley S.D. 2004. Advanced backcross QTL analysis of a Lycopersicon esculentum $\times$ L. pennellii cross and identification of possible orthologs in the Solanaceae.
Theor. Appl. Genet. 108(3): 485-496. DOI: 10.1007/s00122-003-1422-x

Frary A., Xu Y., Liu J., Mitchell S., Tedeschi E., Tanksley S. 2005. Development of a set of PCRbased anchor markers encompassing the tomato genome and evaluation of their usefulness for genetics and breeding experiments. Theor. Appl. Genet. 111: 291-312. DOI: 10.1007/s00122-0052023-7

Gashaw A., Mohammed H., Singh H. 2007. Genetic divergence in selected durum wheat genotypes of Ethiopian plasm. Afr. Crop. Sci. J. 15(2): 67-72. DOI: $10.4314 /$ acsj.v15i2.54419

Grandillo S., Tanksley S.D. 1996. Genetic analysis of RFLPs, GATA microsatellites and RAPDs in a cross between $L$. esculentum and L. pimpinellifolium. Theor. Appl. Genet. 92(8): 957-965. DOI: 10.1007/BF00224035

Kawar P.G., Devarumath R.M., Nerkar Y. 2009. Use of RAPD markers for assessment of genetic diversity in sugarcane cultivars. Indian J. Biotechnol. 8: 6771.

Keneni G., Jarso M., Wolabu T., Dino G. 2005. Extent and pattern of genetic diversity for morphoagronomic traits in Ethiopian highland pulse landraces: I. Field pea (Pisum sativum L.). Genetic Resour. Crop. Ev. 52(5): 539-549. DOI: 10.1007/s10722-003-6016-6

Klein-Lankhorst R.M., Vermunt A., Weide R., Liharska T., Zabel P. 1991. Isolation of molecular markers for tomato (L. esculentum) using random amplified polymorphic DNA (RAPD). Theor. Appl. Genet. $\quad 83(1)$ : 108-114. DOI: 10.1007/BF00229232

Miller J.C., Tanksley S.D. 1990. RFLP analysis of phylogenetic relationships and genetic variation in the genus Lycopersicon. Theor. Appl. Genet. 80: 437448. DOI: $10.1007 / \mathrm{BF} 00226743$

Mondini L., Noorani A., Pagnotta A. Mario. 2009. Assessing plant genetic diversity by molecular tools. Diversity 1: 19-35. DOI: 10.3390/d1010019

Nei M. 1973. Analysis of gene diversity in subdivided population. Proceed. Natl. Acad. Sci. USA. 70: 3321-3323. DOI: 10.1073/pnas.70.12.3321

Noli E., Cont S., Maccaferri M., Sanguineti M.C. 1999. Molecular characterization of tomato cultivars. Seed Sci. Technol. 27(1): 1-10.

Park Y.H., West M.A.L., St. Clair D.A. 2004. Evaluation of AFLPs for germplasm fingerprinting and assessment of genetic diversity in cultivars of tomato (Lycopersicon esculentum L.). Genome 47: 510-518.

Parmar P., Oza P. Vishal., Chauhan V., Patel A.D., Kathiria K.B., Subramanian R.B. 2010. Genetic diversity and DNA fingerprint study of tomato discerned by SSR markers. Int. J. Biotechnol. Biochem. 6: 657-666. 
Rajput S.G., Wable K.J., Sharma K.M., Kubde P.D., Mulay S.A. 2006. Reproducibility testing of RAPD and SSR markers in tomato. Afr. J. Biotechnol. 5(2): 108-112.

Rana M.K., Vafai Tabar M., Bhat K.V. 2005. Genetic diversity in Indian cotton (Gossypium spp.) cultivars as revealed by RAPD analysis. Indian J. Biotechnol. 4: 522-527.

Rick C.M. 1975. The tomato. In: King R.C. (ed.), Handbook of Genetics. New York, NY, USA. Plenum Press, Vol. 2: 247-280. DOI: 10.1007/978-1-4684-2994-711

Roubos K., Moustakas M., Aravanopoulos F.A. 2010. Molecular identification of Greek olive (Olea europaea) cultivars based on microsatellite loci. Genet. Mol. Res. 9(3): 1865-1876. DOI: 10.4238/vol9-3gmr916

Saliba-Colombani V., Causse M., Gervais L., Philouze J. 2000. Efficiency of RFLP, RAPD, and AFLP markers for the construction of an intraspecific map of the tomato genome. Genome 43: 29-40. DOI: $10.1139 / \mathrm{g} 99-096$

Semagn K., Bjørnstad A., Ndjiondjop Mn. 2006. An overview of molecular marker methods for plants. Afr. J. Biotechnol. 5(25): 2540-2568.

Sharifova S.S. 2012. Biodiversity of vegetable genetic resources in Azerbaijan. Proc. Intern. Scientific Conference "130 Years Agricultural Science in Sadovo", Institute of Plant Genetic Resources, Sadovo, Bulgaria, 5-6 June 2012, pp: 12-15.

Singh N., Singh M., Kumar S., Kumar R., Singh V., Prasanna H.C., Rai M. 2007. RAPD markers for hybrid seed purity testing in tomato (Solanum lycopersicum L.). Cur. Sci. 93(4): 462-463.

SPSS, SPSS Base 12.0 for Windows User`s Guide, SPSS Inc., Chicago, IL., 2003.

Suliman-Pollatschek S., Kashkush K., Shats H., Hillel J., Lavi U. 2002. Generation and mapping of AFLP, SSRs and SNPs in Lycopersicon esculentum. Cel. Mol. Biol. Lett. 7: 583-597. DOI: 10.1007/BF00279708

Tanksley S.D., Ganal M.W., Prince J.P., De-Vicente M.C., Bonierbale M.W., Broun P., Fulton T.M., Giovannoni J.J., Grandillo S., Martin G.B et al. 1992. High density molecular linkage maps of the tomato and potato genomes. Genetics 132(4): 1141-1160.

Tanksley S.D., Rick C.M. 1980. Isozymic gene linkage map of the tomato: applications in genetics and breeding. Theor. Appl. Genet. 58(2): 161-170.

Tardin F.D., Amaral Júnior A.T., Pereira M.G., Vidigal M.C.G., Daher R.F., Scapim C.A. 2003. Genetic diversity and determination of the optimum number of RAPD markers in lettuce (Lactuca sativa L.). Acta Sci-Agron. 25(1): 1-5.

Teixeira-Cabral T.A., Sakiyama N.S., Zambolim L., Pereira A.A., Barros E.G., Sakiyama C.C.H. 2002. Reproducibility of the RAPD marker and its efficiency in coffee tree genotype grouping analysis. Crop Breed. Appl. Biotechnol. 2(1): 121-129.

Zvingila D., Verbylaitë R., Baliuckas V., Pliura A., Kuusiene S. 2005. Genetic diversity (RAPD) in natural Lithuanian populations of common ash (Fraxinus excelsior L.). Biologija 3: 46-53. 